\title{
THE ARCHITECTURE OF
}

SPATIAL JUSTICE

\section{Keywords}

Politics

Social role

Ethics

Equity

Public
In the second decade of the $27^{\text {st }}$

century, there is a certain consensus that architecture has a close - rather ontological - relationship with politics. However, when we ask which political option certain architecture defends, debate sparks off. The following selection of ten projects includes those cases where creation, opening, and formalization of spaces - what architecture does - has been a way of approaching an ideal of social justice.

ustice is not a matter enclosed within the boundaries of the social sphere. Space produces and reproduces power, capital, class and cultural relations - just to name a few. In space, thus, conditions of opportunity for some and marginality for others materialize. Within this arena where huge forces struggle, the role of architecture seems minor - although it can have transformative effects if it manages to make room for equity. Designing for social justice, for a public project of space, entails big challenges that push the task beyond the limits of convention.

Political awareness of the social role of architecture can be read in the historical incidence of prominent architects in the provision of social housing. In large-scale operations, such as Villa La Reina, or in more precise and experimental strategies, as Quinta Monroy, 


\section{PÍA MONTEALEGRE}

Directora de Investigación y Publicaciones

Facultad de Arquitectura y Diseño,

Universidad Finis Terrae mobilization of knowledge has been aimed at improving the living conditions of the most vulnerable ones. Such works answer, in general, to political commissions of larger agendas, where architecture must learn how to go along with the same discretion of a musician within a big orchestra. As a general rule, works are designed to minimize economic resources and maximize their possibilities. The rational features of practice are challenged to harness the potential of what already exists, as in the strategy of turning the Mapocho River into a cycle road.

Sometimes the commission also entails the difficult task of founding places of hope in precarious and deteriorated landscapes, as in the case of the libraries in Medellín, the Residencial Parque Novo Santo Amaro V - in the heart of São Paulo's favelas - or the MINvU's Urban Parks Program in the gos. The effects of these works must be perceived beyond their objective and theoretical limits, recomposing not only the place's physical landscape, but also the affective relations of citizens with their surroundings. Thus, projects such as the Rehabilitation of Unión Obrera at Cordillera hill advocate for the dignity of a community's memory.

Although design is a decisive factor in the sense of appropriation that people profess for spaces, creative freedom must be balanced in order to facilitate a political management that preserves them over time. Sometimes works are at the edges of discursive presence, either because of their subtlety or for being discreetly subsumed in a morphology that observes technical problems, as in the case of Santiago's subway Line 6. On the other hand, the work aimed at the public must play 
by the rules of speculation and meet the requirements of an anonymous - but nevertheless present - user.

An architecture that must learn to lower its voice in a scenario where others are the main characters.

Sometimes, architectural image is pondered until becoming a language of natural reassembling - as it happens in Kaukari park's landscape strategy, which recovers the Copiapó river for the city. On other occasions, language works as a declaration of strength, especially when public projects build gestures of justice by rescuing territories removed from urban life - as the Manzanares river park that covered the M-30 motorway in Madrid.

The works that aspire to build justice in space materialize an ethic of discrete but strategic objectives, where architectural thinking has more dimensions than those of the built artifact. ARQ

Pía Montealegre

$<$ pmontealegreb@gmail.com>
Architect, Master in Architecture and Doctorate in Architecture and Urban Studies, Pontificia Universidad Católica de Chile. Director of Research and Publications, Faculty of Architecture and Design, Universidad Finis Terrae. Her lines of research relate to urban history, public space, landscape and memory. She teaches courses on theory and practice of urban planning in various universities in Chile. Likewise, she has professional experience related to the design of public spaces. 
VILLA LA REINA

Equipo de proyecto / Project team:

Municipalidad de La Reina, Pontificia

Universidad Católica de Chile, IN ACAP y

futuros pobladores

1966

Publicado en / Published in

$A R Q 86$ (diciembre, 2002): 31-43
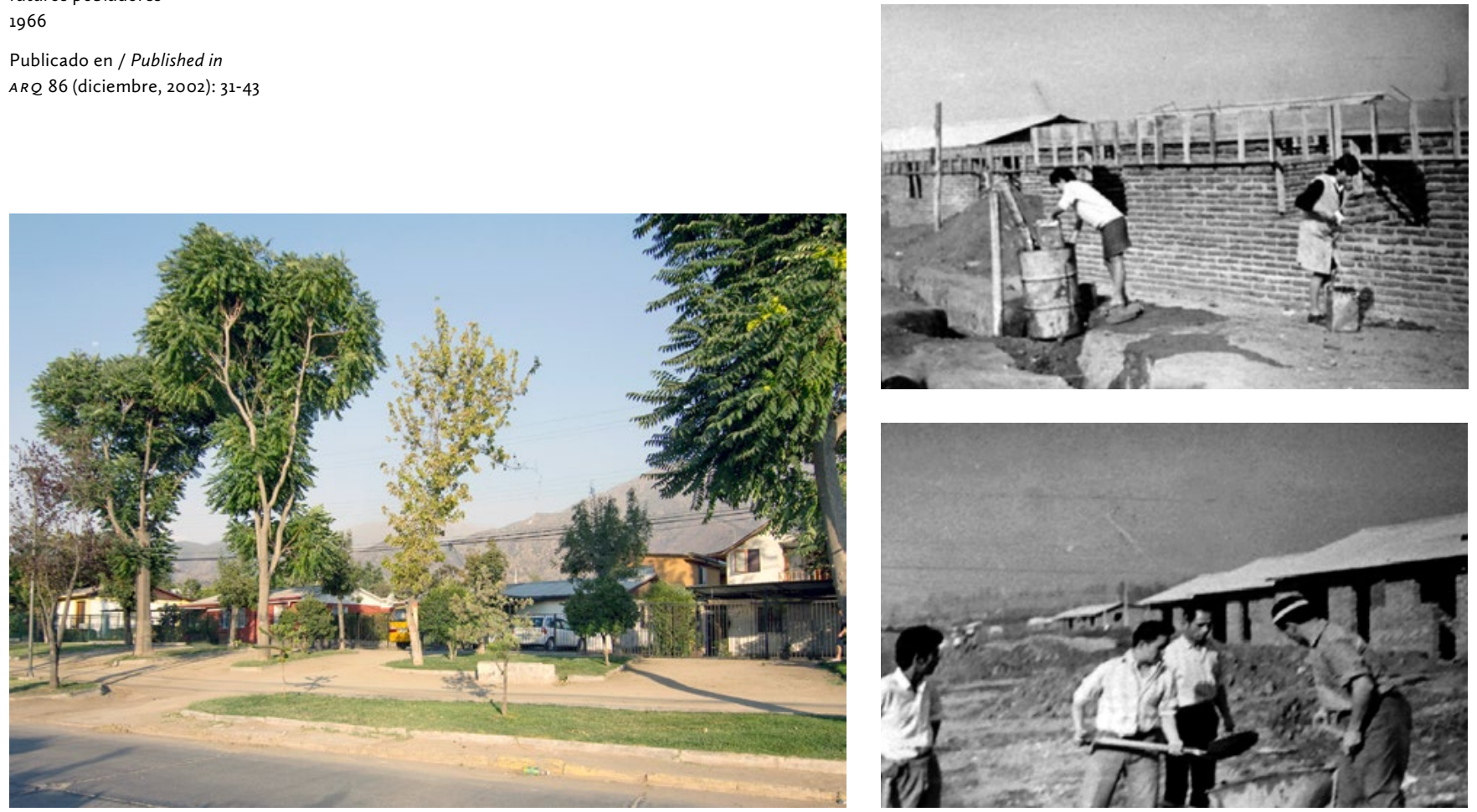

PROGRAMA DE PARQUES URBANOS

EN SANTIAGO

Equipo de proyecto / Project team: Sergio León, Pablo Trivelli, Francisco Schmidt, M.

Angélica Alvarado, M. Teresa Ugarte, M. Isabel Alonso, A. María del Valle
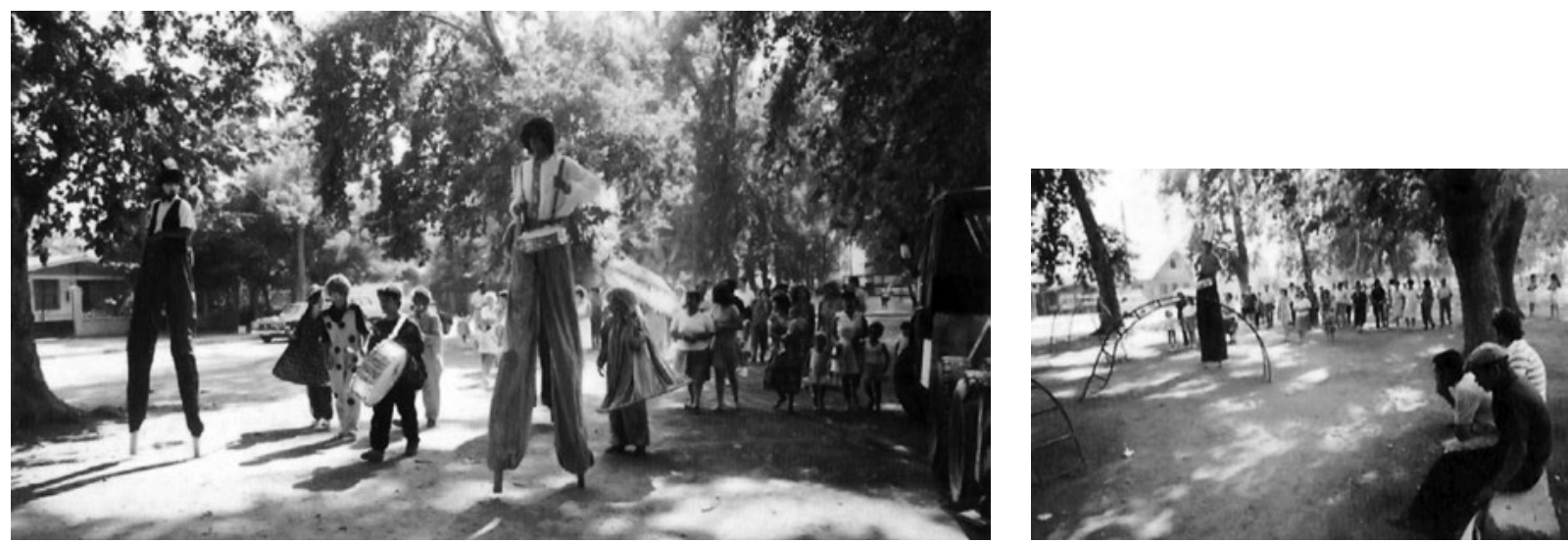
DOS BIBLIOTECAS EN MEDELLÍN

Giancarlo Mazzanti

2007

Publicado en / Published in

ARQ 71 (abril, 2009): 20-31
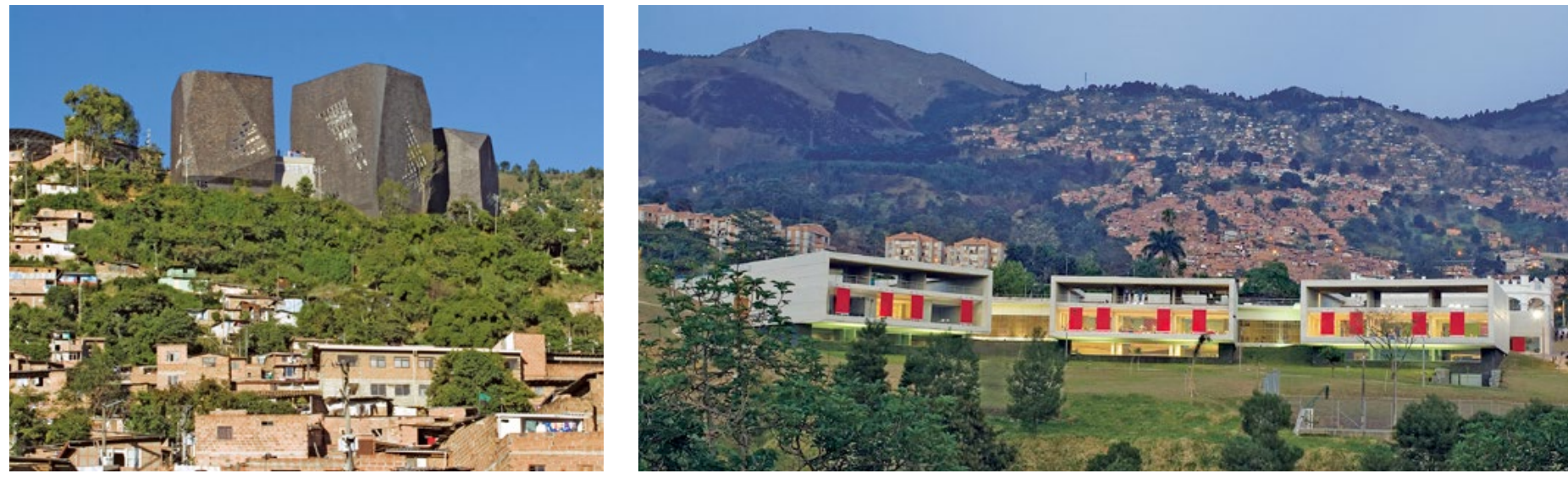

PARQUE RÍO MANZANARES

Burgos \& Garrido Arquitectos S.L., Porras \& La Casta Arquitectos S.C.P., Rubio \& Álvarez-Sala Arquitectos, West 8 - Urban Design \& Landscape Architecture B.v. 2011

Publicado en / Published in ARQ 72 (agosto, 2009): 20-25

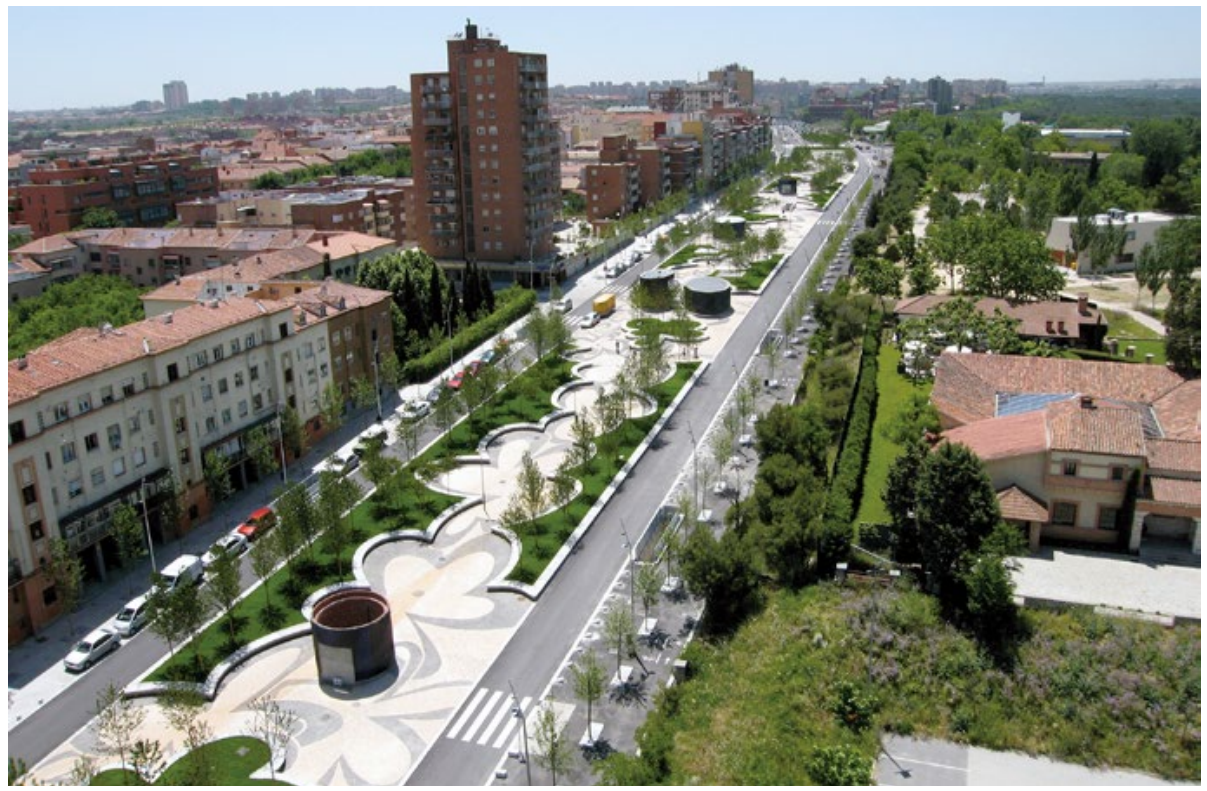


RESIDENCIAL PARQUE NOVO SANTO AMARO V

Héctor Vigliecca, Luciene Quel, Neli Shimizu, Ronald Werner, Caroline Bertoldi, Kelly Bozzato, Pedro Ichimaru, Bianca Riotto, Mayara Rocha Christ, Fábio Pittas, Thaísa Fróes,

Aline Ollertz, Sérgio Faraulo, Paulo Serra, Luci Maie

2012

Publicado en / Published in ARQ 86 (abril, 2014): 88-92

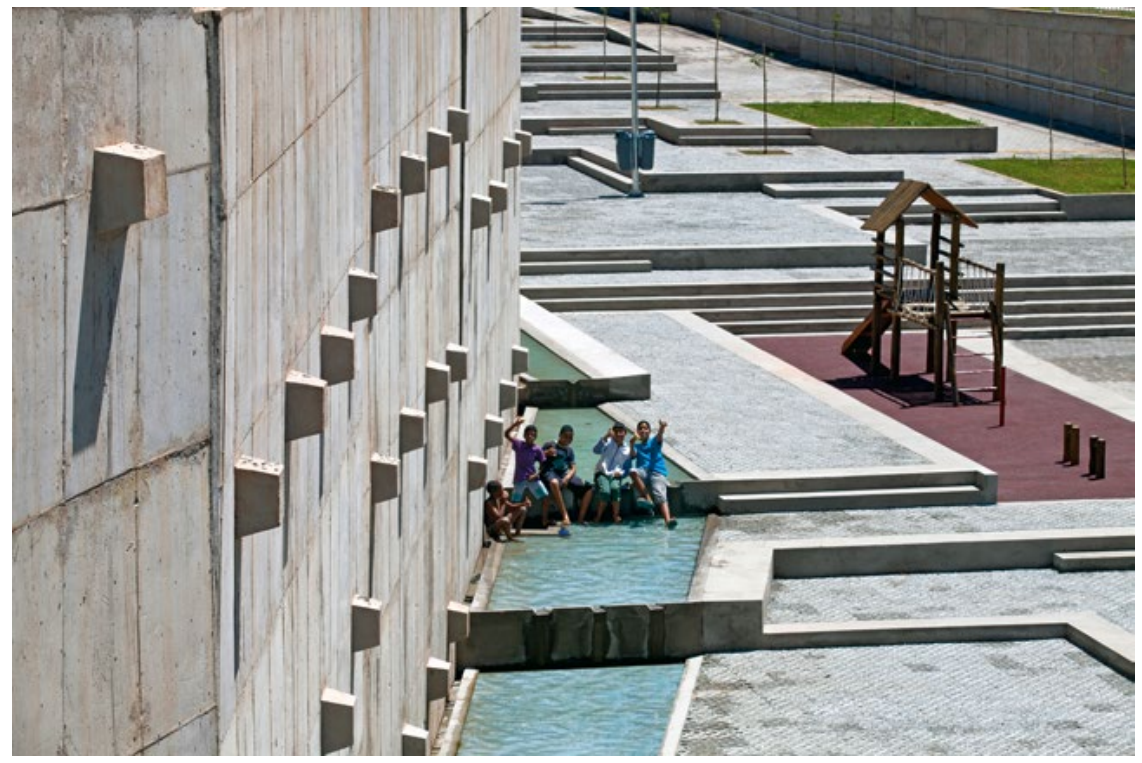

MAPOCHO PEDALEABLE,

SANTIAGO, CHILE

Tomás Echiburú, Osvaldo

Larrain

2013

Publicado en / Published in $A R Q 85$ (diciembre, 2013): 48-51

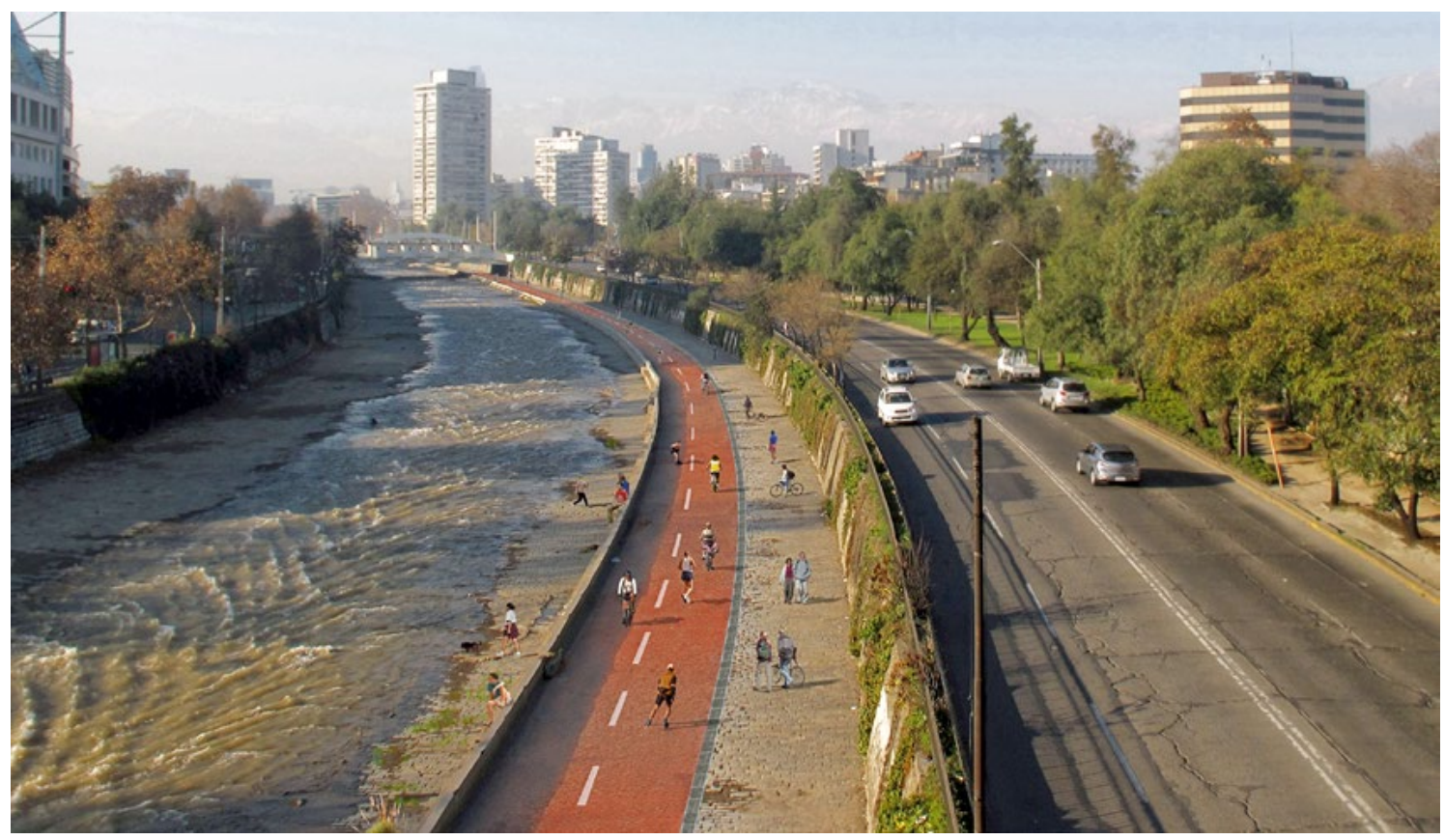




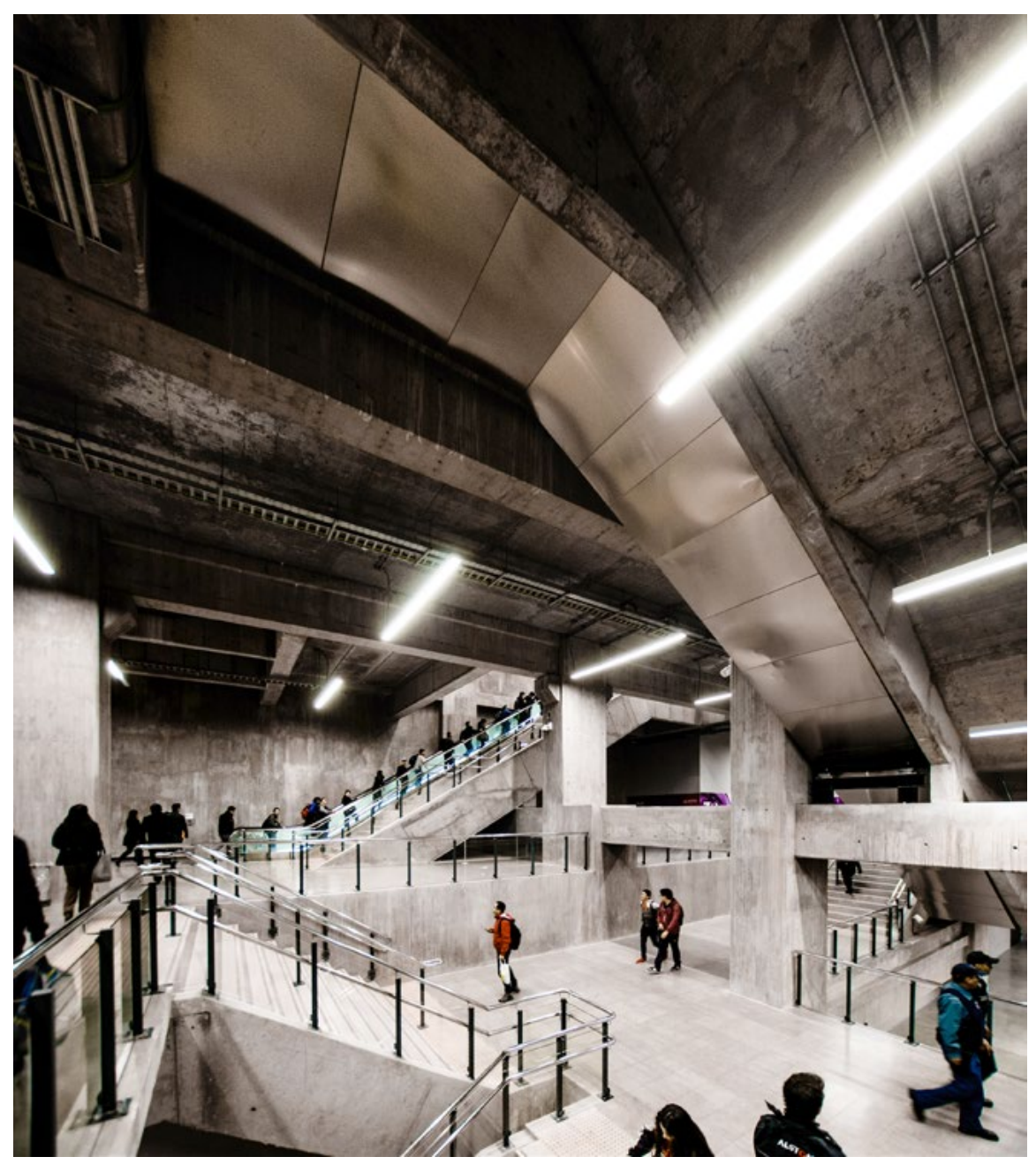

LÍNea 6 del METRo de

SANTIAGO: BAJO EL LENTE

DE UN USUARIO

MOBIL Arquitectos, ACXT

Arquitectos (IDOM)

2017

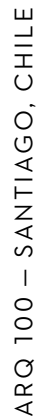

Publicado en / Published in

ARQ 98 (abril, 2018): 54-65

PARQUE KAUKARI

DEL RÍO COPIAPÓ

Teodoro Fernández Arquitectos.

Teodoro Fernández, Paulina Courard,

Macarena Gaete, Milva Pesce,

Benjamín López

2018

Publicado en / Published in

ARQ 99 (agosto, 2018): 70-82

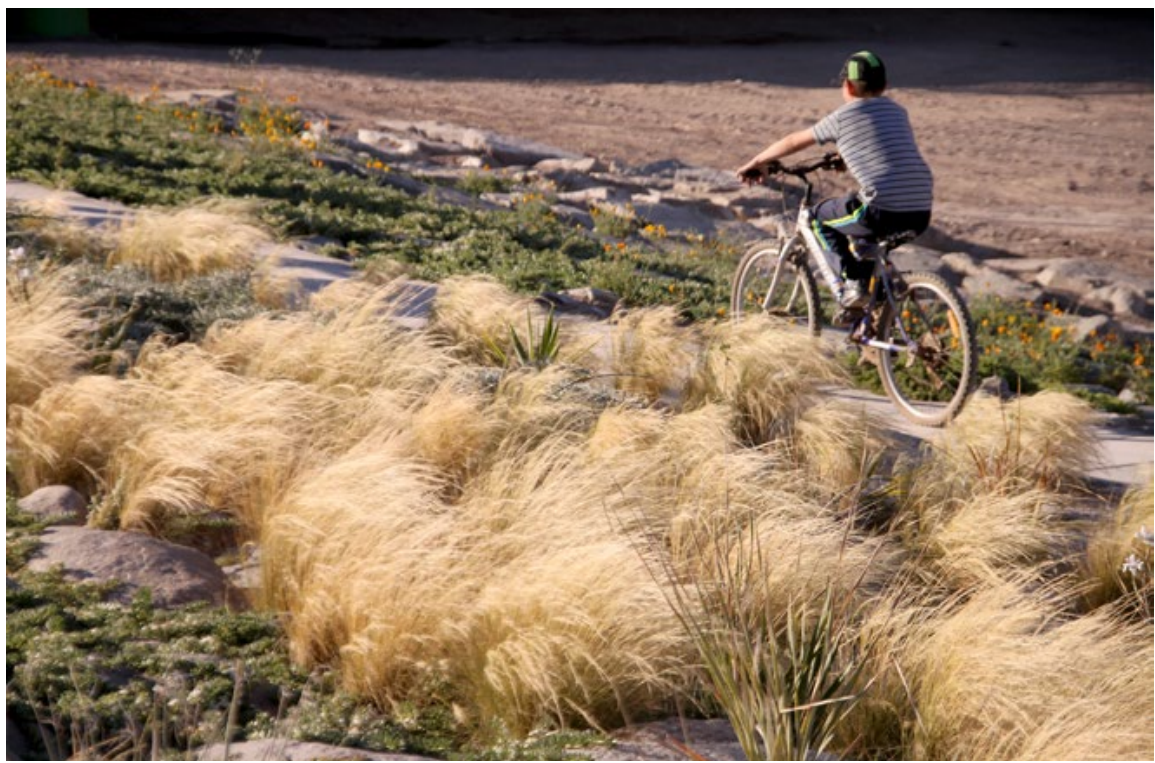

